\title{
Morphological Characterization of Cephaleuros virescens Occurring in Mango Trees
}

\author{
Camila Vilela Vasconcelos ${ }^{1}$, Paulo Henrique Pereira Costa Muniz ${ }^{1}$, Elizabeth Amélia Alves Duarte ${ }^{2}$, \\ Thiago Alves Santos de Oliveira ${ }^{3}$, Wanderson Silva dos Santos ${ }^{1}$, Maria Eduarda Sampaio Barboza ${ }^{1}$, \\ Fabricio Rodrigues ${ }^{1} \&$ Daniel Diego Costa Carvalho ${ }^{1}$ \\ ${ }^{1}$ Universidade Estadual de Goiás, Câmpus Ipameri, Ipameri, Goiás, Brazil \\ ${ }^{2}$ Faculdade Maria Milza, Governador Mangabeira, Bahia, Brazil \\ ${ }^{3}$ Universidade Estadual de Feira de Santana, Feira de Santana, Bahia, Brazil \\ Correspondence: Daniel Diego C. Carvalho, Laboratório de Fitopatologia, Universidade Estadual de Goiás, \\ Rodovia GO 330, km 241, Anel Viário, Setor Universitário, 75780-000, Ipameri, Goiás, Brazil. Tel: \\ 55-643-491-1556. E-mail: daniel.carvalho@ueg.br
}

Received: April 20, 2019

doi:10.5539/jas.v11n11p156
Accepted: May 20, $2019 \quad$ Online Published: July 31, 2019

URL: https://doi.org/10.5539/jas.v11n11p156

\begin{abstract}
The objective of this work was to accomplish the micromorphological characterization of the causal agent of the algal spot in 'Amrapali' mango trees. Therefore, 'Amrapali' mango leaves exhibiting symptoms of algal spots were used for making microscope slides, on which the pathogen somatic and reproductive structures were measured. The dimensions obtained for sporangiophores and sporangia were 245.5-545.6 $\times 10.5-19.1 \mu \mathrm{m}$ and 21.4-34.2 $\times 16.3-24.7 \mu \mathrm{m}$, respectively. Descriptions based on symptoms and micromorphology indicated that the algae are Cephaleuros virescens, since this morphological data corroborates with literature descriptions. Besides, the algae had already identified by DNA sequencing as $C$. virescens.
\end{abstract}

Keywords: algal spot disease, taxonomy, Mangifera indica

\section{Introduction}

Brazil is the third largest fruit producer in the world, with a territorial extension of 8.5 million square kilometers of planted area. Mango production (Mangifera indica L.) is in great expansion because of its wide acceptance in the domestic and foreign markets, being one of the fruits most exported mainly to the European market, reaching compensating prices (Souza et al., 2016). Mango is considered one of the most important tropical fruits cultivated in the world, in which Brazil is the seventh largest producer in the world, with the largest producing region being the Northeast (Lima et al., 2009). In 2017, Brazil produced approximately 1,087,091 thousand tons of mango in an area of 63.9 thousand ha, being exported more than 154.211 thousand tons of the fruit, being the second fruit most exported by the country in volume, and the first in revenue (IBGE, 2018).

However, many problems are found in the chain of production of this crop, such as diseases caused by microorganisms, which in many cases are limiting their commercial exploitation in view of qualitative and quantitative losses (Batista et al., 2016). Among these microorganisms, Cephaleuros sp. is a green algae of the kingdom Archaeplastida, filo Chlorophyta, class Ulvophyceae, order Trentepohliales, family Trentepohliaceae, which parasites several host plants causing the disease known as algae spot, which occurs in all tropical and subtropical regions of the world, between latitudes $32^{\circ} \mathrm{N}$ and $32^{\circ} \mathrm{S}$, as long as temperature and humidity are adequate for their growth and reproduction (Nelson, 2008; Malagi et al., 2011).

The algae genus Cephaleuros spp. compound of 15 species, consists of branched, free or coalescing filaments, which form irregular discs that grow underneath the cuticle and epidermis of leaves of higher plants and cause leaf spots and stems of over 200 species of plants, mainly in the tropics. Cephaleuros, commonly referred to as a mandatory epiphyte, may also be parasitic, where haustoria are sometimes present within the tissues of the host plant (López-Bautista, Rindi, \& Guiry, 2006). In addition, the pathogen is more frequent in high temperature and humidity conditions, especially in the more shaded leaves of the plant (Ponmurugan, Saravanan, \& Ramya, 2010). The symptoms are circular spots of orange color and felt-like texture, with time, tend to expand, presenting a smooth surface and a gray-brown color, occupying a large leaf volume (Ponmurugan et al., 2009; 
Vasconcelos et al., 2016). As a consequence of the large leaf volume occupied, the damage caused is due to the reduction of the photosynthetic area of the leaves (Ponmurugan et al., 2007; Malagi et al., 2011).

In the case of morphological studies of microorganisms, mainly focused on the characterization and taxonomy of several groups, such as micro-fungi, spores and other propagation structures are measured in their dimensions, such as length and width (Carvalho et al., 2008). In the case of organisms from other groups, there are other important propagation structures for the taxonomy, such as the sporangia of the algae and the organisms of the Chromista kingdom (Thompson \& Wujek, 1997), and fundamentally the dimensions are measured in a way similar to the Fungi kingdom fungi. In studies on the Cephaleuros morphological characteristics, the number of sporangia by sporangiophore and the length and width of sporangiophores and sporangia are commonly estimated (Han et al., 2011; Vasconcelos et al., 2016), so there is no standard for the distinctive morphological characters. Recently, physiological and molecular characterization of Cephaleuros virescens Kunze occurring in mango trees was done (Vasconcelos et al., 2018). Therefore, the objective of this study was to carry out the micromorphological characterization of Cephaleuros occurring on mango from the previously mentioned work.

\section{Method}

\subsection{Micromorphological Characterization}

'Amrapali' mango leaves showing algae spots were collected from 8-year-old trees (Setember of 2014), from an orchard located within Goiás State University (UEG), Ipameri Campus, Goiás, Brazil $\left(17^{\circ} 43^{\prime} 00.38^{\prime \prime}\right.$ S, $48^{\circ} 08^{\prime} 40.96^{\prime \prime} \mathrm{W}, 796 \mathrm{~m}$ ). Then, the leaves were subjected to a humid chamber condition using transparent Gerbox $(11 \times 11 \times 3.5 \mathrm{~cm})$ containing a sheet of blotting paper, previously wetted with sterile distilled water (SDW) to 2.5 times its weight. The wet condition was maintained for 5 days until the lesions became larger in size and protruding. Then microscope slides were made using SDW as the mounting medium. Images of the algal structures were generated in a Leica DM500 light microscope with an ICC 50 digital camera attached. Measurements of the structures were performed using LAS EZ 2.0 software, with an average of 40 measurements for each structure. The algal structure measurement results were subjected to variance analysis with the help of SISVAR 5.3 software (Ferreira, 2011).

\section{Results}

Circular-shaped (Figure 1A) and coalescing (Figure 1B) lesions, orange in color and with velvet-like texture scattered on the adaxial surface were seen in 'Amrapali' mango tree leaves. Leaves injured by $C$. virescens occurred mainly in the basal part of the plants with high infestation. After algal structure measurement, it was found that the sporangiophores occurring in clumps (Figure 2A) or individually (Figure 2B) had 245.0-545.0 $\times$ $10.5-19.1 \mu \mathrm{m}(431.0 \times 12.9 \mu \mathrm{m})($ Table 1$)$, while the sporangia showed 21.4-34.2 $\times 16.3-24.7 \mu \mathrm{m}(27.8 \times 20.3 \mu \mathrm{m})$ (Figures 2B and 2D). The number of sporangiophore septa varied from 4-9 (Figure 2C), averaging 5.6 septa per sporangiophore. The total number of sporangia produced by each sporangiophore was 2 to 7 , with 3.9 on average, being 2.4 attached and 1.5 detached from the suspensor cells (Figure 2C). The head cells had dimensions of 26.3-55.5 × 22.2-59.0 $\mu \mathrm{m}(35.5-34.6 \mu \mathrm{m})($ Figure $2 \mathrm{C})$.

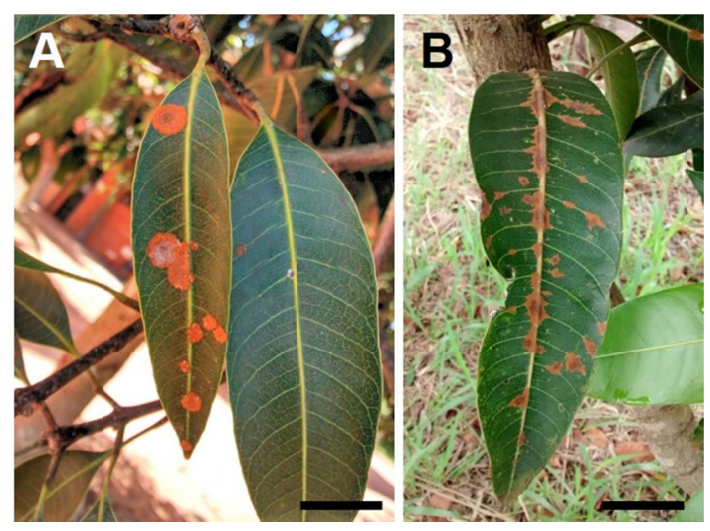

Figure 1. Spots on 'Amrapali' mango tree leaves (Mangifera indica) caused by Cephaleuros virescens with protruding aspect and orange in color. (A) Circular-shaped spots; (B) Coalescing spots. Bars (A and B $=6.5$ and $1.5 \mathrm{~cm}$, respectively) 


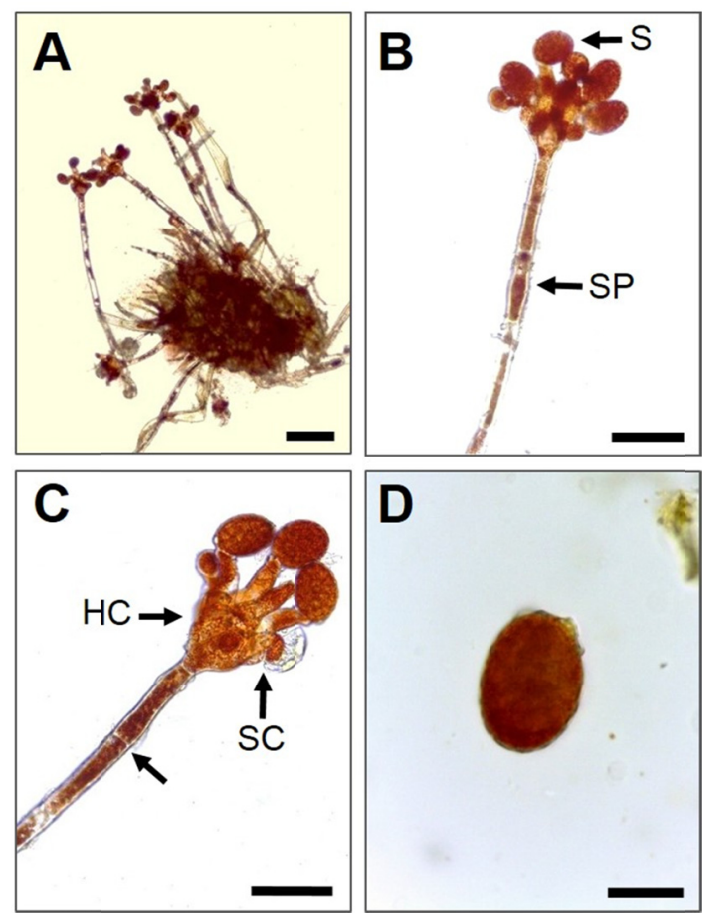

Figure 2. Micromorphological characteristics of Cephaleuros virescens. (A) Clumped sporangiophores; (B) Single sporangiophore (SP: sporangiophore; S: sporangium); (C) Head cell (HC) and Suspensor cell (SC) (isolated arrow indicates a septum in the sporangiophore); (D) Sporangium in enhanced detail. Bars (A, B, C and D = 27.5; 52.1; 56.9 ; and $37.4 \mu \mathrm{m}$, respectively)

\section{Discussion}

In a previous work, the molecular identification of the causal agent of the algal spot was made using mycelium obtained from leaf lesions (Figure 1) and pure algae colonies grown in culture medium. Just after, descriptions based on DNA sequencing indicated that the algae were Cephaleuros virescens (Vasconcelos et al., 2018). Therefore, in this study, attempts have been made to make a micromorphological characterization of Cepahleuros from "Amrapali" mango tress in UEG. Similary, other works carried out the molecular identification and morphological characterization reporting similarity between the results, pointing the same species of the causal agent of the disease in the two methods of taxonomic characterization (Pitaloka et al., 2015; Sunpapao et al., 2016).

Based on the micromorphological characteristics, it was found that the measurements obtained for the sporangiophore (245.0-545.0 $\mu \mathrm{m} \times 10.5-19.1 \mu \mathrm{m})$ of the algae found in mango trees were close to those obtained for C. virescens in Ficus benghalensis plants in Korea by Han et al. (2011), whose measurements were 500$1000 \mu \mathrm{m} \times 12.0-25.0 \mu \mathrm{m}$. Several authors have reported the occurrence of Cephaleuros, however the species $C$. virescens and $C$. parasiticus are the most occurring in the world. In several studies of morphological characterization, comparisons were made between the morphological characteristics of the species, C. virescens, C. parasictus and C. diffusus, being species of greater morphological similarities (Suto et al., 2014; Pitaloka et al., 2015). Less occurring, but that have some similarity with the specie of the present study is C. biolophus (Suto \& Othani, 2009).

In $C$. virescens, the vegetative stem develops only on the leaf adaxial surface, from which the sporangia emerge and the thalli grows only subcuticularly, and only the epidermal and palisade cells are affected. Conversely, $C$. parasiticus lesions develop in the leaf tissue from the adaxial to the abaxial surface, being visible on both surfaces and having protruding sporangiophores primarily from the abaxial leaf surface and rarely from the adaxial surface. Also, in C. parasiticus the vegetative thalli grow subepidermally and intramatrically, where host cell necrosis is observed throughout the leaf tissue (Suto et al., 2014). In accordance with Thompson and Wujek (1997), it is important to mention that the $C$. virescens sporangia found in mango trees $(21.4-34.2 \times \mu \mathrm{m}$ 16.3-24.7 $\mu \mathrm{m}$ ) were bigger than the C. parasiticus sporangia found in Camellia sinensis (17.4-27.5 × 17.4-20. $\mu \mathrm{m})$ by Ponmurugan et al. (2010). Nonetheless, it can be stated that the sporangiophore size is a safer feature to 
distinguish the two species, since Suto et al. (2014) have stated that the sporangium size is the same for $C$. virescens and $C$. parasiticus. Although $C$. virescens and C. parasiticus have similarities in shape and coloration, the $C$. parasiticus sporangiophores have higher dimensions for length and width: 880-1256 $\mu \mathrm{m} \times 22.5-32.2 \mu \mathrm{m}$ (Ponmurugan et al., 2010), mainly for $C$. virescens width (14.0-19.0 $\mu \mathrm{m}$ ), as observed by Suto et al. (2014).

More broadly, a distinctive feature that allows to separate $C$. virescens from C. biolophus is the termination of the head cell. In C. virecens it is only terminal, whereas in C. biolophus it is terminal and lateral. Other characteristics that allow the distinction of these species are the habitat and the size of the sporangiophore. $C$. virescens occurs only subcuticularly on upper leaf surface, whereas C. biolophus occurs subcuticularly, subepidermarlly e intramatrically, on upper sometimes lower leaf surface. In addition, the sporangiophore length is lower in C. biolophus $(100-200 \mu \mathrm{m})$ than in C. virescens $(245-545 \mu \mathrm{m})$ (Suto \& Othani, 2009).

Cephaleuros virescens and $C$. diffusus have similarities regarding sporangiophore coloration and length and sporangium width. However, the sporangiophore width is lower for C. diffusus (10-12.5) compared to $C$. virescens (10.5-19.1). Similarly, the sporangium length is lower for $C$. diffusus (12.5-27.5) than $C$. virescens (21.4-34.2). The thalli of $C$. virescens forms circular discs without gaps crenate or entire margin, whereas $C$. diffusus formed raised spots (Sunpapao \& Pitaloka 2015). The thallus growth habit of $C$. virescens is pseudoparenchymatous, whereas $C$. diffusus is open filamentous. In addition, $C$. diffusus presents a greater similarity with $C$. parasiticus, so much that they can not be distinguished only by the morphology (Thomas et al., 2016).

It is important to note that not all micromorphological features are completely evaluated in several studies published. The most measured features are sporangium and sporangiophore length and width, or just one of them, often only the average values obtained for the measurements being described, while it would be more appropriate to refer to the ranges obtained for each structure. Another important point is the data variability, where coefficient of variation of $18.5 ; 14.2 ; 11.22$ and $7.93 \%$ for sporangiophore and sporangium length and width, respectively, were obtained. Thus, for Cephaleuros micromorphological characterization the following structures need to be measured: length and width of (a) sporangiophores, (b) sporangia, (c) head cells; number of (d) sporangia per sporangiophore, (e) sporangia attached to suspensor cells, (f) sporangia detached from suspensor cell; $(\mathrm{g})$ number of septa per sporangiophore; and $(\mathrm{h})$ coefficient of variation for sporangiophore and sporangium length and width (Vasconcelos et al., 2016).

According to Malagi et al. (2011), the occurrence of the algae is favored by high temperatures and high relative humidity. During September of 2014, the temperature in the city of Ipameri showed maximum values ranging from 29 to $42{ }^{\circ} \mathrm{C}$, a condition that, associated to the $14.4 \mathrm{~mm}$ precipitation, favored the development of the disease. This is corroborated by the work of Muthukumar, Uma and Priyadharsini (2014), which reports the occurrence of algae and lesions being restricted to the rainy season and high temperatures in several plant species, suggesting that optimal environmental conditions may be decisive for the development of the disease in certain susceptible hosts. It is worth noting that the lesions of circular and coalescing, orange and velvet texture scattered on the adaxial surface observed in the leaves of 'Amrapali' mango leaves, corroborate with the symptomatology described by Suto et al. (2014) for C. virescens species.

\section{Conclusion}

Descriptions based on the symptoms together with the morphological characterization indicated that the algae found in 'Amrapali' mango tree is Cephaleuros virescens.

\section{References}

Batista, D. C., Ribeiro Júnior, P. M., Barbosa, M. A. G., Andrade, J. N., \& Terno, D. (2016). Mango diseases. Informe Agropecuário, 37(290), 82-91.

Carvalho, D. D. C., Alves, E., Batista, T. R. S., Camargos, R. B., \& Lopes, E. A. G. L. (2008). Comparison of methodologies for conidia production by Alternaria alternata from citrus. Brazilian Journal of Microbiology, 39(4), 792-798. https://doi.org/10.1590/S1517-83822008000400036

Ferreira, D. F. (2011). Sisvar: A computer statistical analysis system. Ciência e Agrotecnologia, 35(6), 1039-1042. https://doi.org/10.1590/S1413-70542011000600001

Han, K., Park, M., Park, J., \& Shin, H. (2011). First report of algal leaf spot associated with Cephaleuros virescens on greenhouse grown Ficus benghalensis in Korea. Australasian Plant Disease Notes, 6(1), 72-73. https://doi.org/10.1007/s13314-011-0024-8 
IBGE (Instituto Brasileiro de Geografia e Estatística). (2018). Produção Agrícola Municipal. Retrieved from https://sidra.ibge.gov.br/pesquisa/pam/tabelas

Lima, C. S., Pfenning, L. H., Costa, S. S., Campos, M. A., \& Leslie, J. F. (2009). A new Fusarium lineage within the Gibberella fujikuroi species complex is the main causal agent of mango malformation disease in Brazil. Plant Pathology, 58(1), 33-42. https://doi.org/10.1111/j.1365-3059.2008.01946.x

López-Bautista, J. M., Rindi, F., \& Guiry, M. D. (2006). Molecular systematics of the subaerial green algal order Trentepohliales: an assessment based on morphological and molecular data. International Journal of Systematic and Evolutionary Microbiology, 56(1), 1709-1715. https://doi.org/10.1099/ijs.0.63990-0

Malagi, G., Santos, I., Mazaro, S. M., \& Guginski, C. A. (2011). Detection of algal leaf spot (Cephaleuros virescens Kunze) in Citrus in Paraná State. Revista Brasileira de Agrociência, 17(1), 148-52.

Muthukumar, T., Uma, E., \& Priyadharsini, P. (2014). Occurrence of foliicolous parasitic alga Cephaleuros virescens on cultivated ornamental plants in southern India. Botanica Lithuanica, 20(2), 87-98. https://doi.org/10.2478/botlit-2014-0012

Nelson, S. C. (2008). Cephaleuros Species, the Plant-Parasitic Green Algae. Plant Disease, 43(1), 1-6.

Pitaloka, M. K., Petcharat, V., Arikit, S., \& Sunpapao, A. (2015). Cephaleuros virescens, the cause of an algal leaf spot on Para rubber in Thailand. Australasian Plant Disease, 10(4), 1-4. https://doi.org/10.1007/ s13314-015-0158-1

Ponmurugan, P., Baby, U. I., \& Rajkumar, R. (2007). Growth, photosynthetic and biochemical responses of tea cultivars infected with various diseases. Photosynthetica, 45(1), 143-146. https://doi.org/10.1007/ s11099-007-0023-3

Ponmurugan, P., Saravanan, D., \& Ramya, M. (2010). Culture and biochemical analysis of a tea algal pathogen, Cephaleuros parasiticus. Journal Phycology, 46(5), 1017-1023. https://doi.org/10.1111/j.1529-8817.2010. 00879.x

Ponmurugan, P., Saravanan, D., Ramya, M., Srinivasan, T. R., Baby, U. U., \& Ajay, D. (2009). Studies on Cephaleuros parasiticus Karst, a pathogenic alga causing red rust disease in tea plantations. Journal of Plantation Crops, 37(1), 70-73.

Souza, S. F., Silva, J. L. M., Guedes, J. P. M., \& Lima, J. R. F. (2016). Competitiveness and market share of brazilian mango exports: An analysis of Constant Market Share model. Revista Econômica do Nordeste, $47(1), 39-48$.

Sunpapao, A., \& Pitaloka, M. K. (2015). A new record of plant parasitic green algae, Cephaleuros diffusus (Trentepohliaceae, Chlorophyta), on Acacia auriculiformis hosts in Thailand. Biodiversitas, 16(2), 116-120. https://doi.org/10.13057/biodiv/d160202

Sunpapao, A., Pitaloka, M. K., \& Arikit, S. (2016). Algal leaf spot associated with Cephaleuros virescens (Trentepohliales, Ulvophyceae) on Nephelium lappaceum in Thailand. Biodiversitas, 17(1), 31-35. https://doi.org/10.13057/biodiv/d170105

Suto, Y., \& Ohtani, S. (2009). Morphology and taxonomy of five Cephaleuros species (Trentepohliaceae, Chlorophyta) from Japan, including three new species. Phycologia, 48(1), 213-236. https://doi.org/ 10.2216/07-31.1

Suto, Y., Ganesan, E. K., \& West, J. A. (2014). Comparative observations on Cephaleuros parasiticus and C. virescens (Trentepohliaceae, Chlorophyta) from India. Algae, 29(2), 121-126. https://doi.org/10.4490/ algae.2014.29.2.121

Thomas, B. T., Thomas, V. P., Bhagya, M. V., Nair, S. S, Rajan, R., \& Saranyamol, S. T. (2016). New Record of Phytoparasitic Alga, Cephaleuros diffusus Thomson \& Wujekin (Trentepohliaceae, Chlorophyta) on Artocarpus incisus (Thunb.) L.f., Kerala, India. International Journal of Modern Botany, 6(3), 37-40. https://doi.org/10.5923/j.ijmb.20160603.01

Thompson, R. H., \& Wujek, D. (1997). Printzina gen. nov. (Trentepohliaceae), including a description of a new species. Journal Phycology, 28(2), 232-237. https://doi.org/10.1111/j.0022-3646.1992.00232.x

Vasconcelos, C. V., Pereira, F. T., Duarte, E. A. A., Oliveira, T. A. S., Peixoto, N., \& Carvalho, D. D. C. (2018). Physiological and Molecular Characterization of Cephaleuros virescens Occurring in Mango Trees. Plant Pathology Journal, 34(3), 1-6. https://doi.org/10.5423/PPJ.OA.09.2017.0194 
Vasconcelos, C. V., Pereira, F. T., Galvão, C. S., \& Carvalho, D. D. C. (2016). Occurrence of algal leaf spot (Cephaleuros virescens Kunze) on avocado in Goiás State, Brazil. Summa Phytopathologica, 42(1), 108-108. https://doi.org/10.1590/0100-5405/2109

\section{Copyrights}

Copyright for this article is retained by the author(s), with first publication rights granted to the journal.

This is an open-access article distributed under the terms and conditions of the Creative Commons Attribution license (http://creativecommons.org/licenses/by/4.0/). 